$\begin{gathered}\text { Науковий вісник НлтУ України } \\ \text { Scientific Bulletin of UNFU } \\ \text { https://nv.nltu.edu.ua }\end{gathered}$
$\begin{array}{r}\text { https://doi.org/10.15421/40290527 } \\ \text { Article received 13.05.2019 p. } \\ \text { Article accepted 30.05.2019 p. } \\ \text { ІІSSN 2519-2477 (online) }\end{array}$

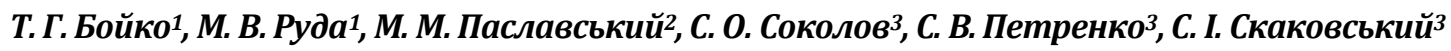

${ }^{1}$ Начіональний університет "Львівська політехніка", м. Львів, Україна

${ }^{2}$ Начіональний лісотехнічний університет Украйни, м. Львів, Украйна ${ }^{3}$ Луганський наиіональний університет ім. Тараса Шевченка, м. Старобільськ, Украйна

\title{
КІБЕРНЕТИЧНА ПРИРОДА СКЛАДНИХ ЛАНДШАФТНИХ КОМПЛЕКСІВ ТА СУПРА-ОПТИМІЗАЦІЯ МЕХАНІЗМІВ САМОВІДНОВЛЕННЯ ТА САМОЗБЕРЕЖЕННЯ
}

Описано кібернетичну сутність і методи керування екологічними процесами в екосистемі, що визначають ії прагнення до самозбереження і самовдосконалення, а отже, неможливі без самовідтворення і самовідновлення. Опрацьовано системноорганізаційні зв'язки у природі та охарактеризовано біосферу як географічну, термодинамічну, хімічну, біотичну та кібернетичну систему. На основі аналізу вітчизняних і зарубіжних літературних джерел визначено особливості самоорганізації, самозбереження і саморегуляції біотичних систем, розкрито механізми саморегуляції екосистем, що дало змогу підійти до обгрунтування складного ландшафтного комплексу (СЛК), як системи. Системність - це загальна властивість об'єктивно існуючої єдності СЛК, їх структурованості та взаємозв'язку. Основну регуляторну функцію, яка забезпечує стійкість і надійність екосистеми, тобто її гомеостазис і гомеорезис, виконує зворотний зв'язок, в основі якого знаходяться внутрішні процеси, внутрішньосистемні зв'язки і відносини (трофічні, інформаційні та ін.), особливо зворотні зв'язки як дія у відповідь одного із внутрішніх компонентів на сильний вплив на нього з боку іншого компонента. Ієрархічність будови біосфери зумовлює й ієрархічність систем регуляції рівноваги (гомеостазу) ії ландшафтних комплексів, компартментів, підсистем та ярусів. Саме ієрархічність просторово-часових характеристик живої матерії дає змогу змоделювати в просторі і часі весь спектр процесів, що забезпечують адаптацію біологічних систем. Вихідні специфічні змінні компартментів формують, з одного боку, деяку сумарну специфічну змінну об'єкта (супра-контуру), а з іншого - $\epsilon$ входами для блоку обчислення його цільової функції, вихід якого $є$ визначальним для організації адаптивної поведінки кожного з компартментів. Отже, схема ієрархічної оптимізації притаманна для організації насамперед природних систем (за цільовими критеріями енергоструктурного характеру). Визначивши процес "супра-оптимізації" як процес безперервної еволюції супра-систем, виділено фундаментальні особливості такого процесу, чітко сформульовано завдання функціональної організації СЛК, а також визначено яруси і зв'язки супра-контуру компартменту. Запропонована концептуальна схема може бути використана як базова модель під час постановки і вирішення найрізноманітніших проблем, що супроводжують надійність біологічної системи, зокрема модель механізму реалізації процесів адаптації та еволюції СЛК.

Ключові слова: складний ландшафтний комплекс; компартмент; біогеоценоз; гомеостази; гомеорезис; супра-контур; системність; ісрархічна оптимізація; екологічна надійність.

Вступ. Екосистема володіє безліччю функцій, серед яких виділяється головна функція біологічного об'єкта, що визначає його прагнення до самозбереження і самовдосконалення, тобто кібернетична сутність екосистеми, яка неможлива без самовідтворення і самовідновлення. Під впливом різних умов у біологічній системі

можуть відбуватися відмови будь-якого іiї елемента, наслідком чого є втрата її основних функцій саморегуляції. 3 огляду на зазначене актуальним $\epsilon$ питання кібернетичної суті і методів керування екологічними процесами в екосистемі.

Засновник кібернетики Норберт Вінер визначав іiі як

\section{Інформація про авторів:}

Бойко Тарас Георгійович, д-р техн. наук, професор, кафедра приладів точної механіки. Email: tgbo@ukr.net; https://orcid.org/0000-0002-0487-3293

Руда Марія Віталіївна, канд. техн. наук, викладач, кафедра екологічної безпеки та природоохоронної діяльності. Email: marichkarmv@gmail.com; https://orcid.org/0000-0003-0590-4589

Паславський Михайло Михайлович, пров. інженер, кафедра екологіï. Email: mykhaylo.paslavskyi@gmail.com; https://orcid.org/0000-0003-1635-4340

Соколов Сергій Олександрович, канд. с.-г. наук, доцент, кафедра садово-паркового господарства та екології. Email: sergiysokolov1967@gmail.com

Петренко Сергій Віталійович, канд. біол. наук, доцент, завідувач кафедри садово-паркового господарства та екології. Email: sergiysokolov1967@gmail.com

Скаковський Сергій Іванович, асистент, кафедра садово-паркового господарства та екології. Email: sergiysokolov1967@gmail.com

Цитування за ДСтУ: Бойко Т. Г., Руда М. В., Паславський М. М., Соколов С. О., Петренко С. В., Скаковський С. І. Кібернетична природа складних ландшафтних комплексів та супра-оптимізація механізмів самовідновлення та самозбереження. Науковий вісник НЛтУ України. 2019, т. 29, № 5. С. 134-140.

Citation APA: Bojko, T. Gh., Ruda, M. V., Paslavskyi, M. M., Sokolov, S. O., Petrenko, S. V., \& Skakovskiy, S. I. (2019). Cibernetic character of composite landscape complexes and supra-optimization of mechanisms of self-repair and self-preservation. Scientific Bulletin of UNFU, 29(5), 134-140. https://doi.org/10.15421/40290527 
науку, що вивчає керування неживими механічними i живими системами. За В. М. Глушковим (Hlushkov, 1973), кібернетика - це "наука про загальні закони одержання, зберігання, передавання і перетворювання інформації у складних керівних системах.

Основними атрибутами усіх саморегульованих систем $є$ наявність власне керованої системи, регулятора, який забезпечує ефект саморегуляції, пам'яті, в якій зберігається інформація про структурно-функціональні властивості саморегульованої системи в мінливих умовах іiї зовнішнього середовища та впливу на неї зовнішніх збурювальних чинників, а також еталонної (гіпотетичної, найбільш відповідної конкретним умовам зовнішнього середовища) системи, зі структурно-функціональними параметрами котрої регулятор постійно порівнює керовану систему. Окрім цього, такі системи повинні мати здатність саморегулювання за трьома типами: за заданою програмою, за замкненим циклом зі зворотним зв'язком і з урахуванням чинників, що зумовлюють відхилення від програми (рис. 1) (Antomonov, 1973; Holubets, 1997; Poletaev, 1958). Важливим є також постулат I. I. Шмальгаузена (Shmalhauzen, 1968) про те, що регуляторні механізми саморегульованих систем завжди містяться всередині цих систем.



Рис. 1. Схема функціонування саморегульованої системи: А) за В. М. Глушковим (Hlushkov, 1973), Б) за Ю. Г. Антомоновим (Antomonov, 1973); КС) керована система (об'єкт керування), Р) регулятор (керівна система), Е) еталонна система, 33Д) зовнішне збурювальне діяння; 1-5) канали інформації: 1) прямий зв'язок, 2) порівняння керованої та еталонної систем, 3) зворотний зв'язок, 4) зовнішні чинники, що зумовлюють відхилення від програми, 5) вихід з керованої системи

Корисними під час розгляду цього питання $\epsilon$, безумовно, праці В. І. Вернадського, а також Г. Ф. Хільмі (Khylymy, 1975), котрий, на основі аналізу системноорганізаційних зв'язків у природі, характеризував біосферу як географічну, термодинамічну, хімічну, біотичну та кібернетичну систему.

Системний підхід до складного ландшафтного комплексу. У науковій та навчальній літературі детально описано історію формування поняття про природну систему, в якій функціонально поєднана сукупність організмів із середовищем їх існування. Першими дослідниками, котрі усвідомили потребу вивчення рослин і тварин "у постійному взаємному розвитку, організації і способі життя серед певних умов", були К. Ф. Рульє (1814-1858 pр.) та його учень М. О. Северцов (18271885 pр.). До найбільшого поширення погляду на екологічну систему як на населення рослинних і тваринних організмів, що знаходяться в певному функціональному зв'язку із середовищем існування, у першій третині XX ст. були схильні гідробіологи П. Д. Рєзвой, М. Я. Ливанов, ботаніки В. М. Сукачев і Б. О. Келлер, зоологи F. Dahl, Ch. Adams, V. E. Shelford, B. В. Станчинський і Д. М. Кашкаров. А. С. Тенслі (Tansley, 1935) дав екологічним системам такий первинний опис: "рослинне угруповання, трактоване як система, що містить не тільки рослини, які його утворюють, але й тварини, існування яких пов'язане 3 наявністю цих рослин, а також усі фізичні і хімічні компоненти безпосереднього оточення чи проживання, які разом утворюють замкнену (самостійну) цілісність. Таку систему можна назвати екотопом (місцем) природного середовища, свого роду житлом (ойкос) для організмів, що його населяють". П. Дювиньо (Diuvyno \& Tanh, 1968) визначає екосистему як "функціональну систему, що містить в себе угруповання живих істот та їх середовище існування", P. Дажо (Dazho, 1975) - як більш-менш стійку систему, яка складається з біоценозу та екотопу - двох нероздільних елементів, що впливають один на одного", а Ю. Одум (Odum, 1986) - як "будь-яку одиницю, (біосистему), що містить всі організми, котрі спільно функціонують (біотичне угруповання) на певній ділянці та взаємодіють 3 фізичним середовищем таким способом, що потік енергії створює чітко визначені біотичні структури й кругообіг речовин між живою та неживою частинами". За В. Я. Федоровим і Т. Г. Гільмановим (Fedorov \& Hylmanov, 1980), екосистема - елементарна одиниця природи на земній поверхні, чи елементарний фрагмент екосфери (за Cole; плівки життя за Вернадським) яка "володіє двома ознаками: 1) відносною стійкістю та автономністю, здатністю до самопідтримання й виконання основних життєвих процесів і 2) неможливістю приєднання сусідніх фрагментів або їх частин без порушення якісної однорідності цього фрагмента". Згідно з М. Ф. Реймерсом та О. В. Яблоковим (Reimers \& Yablokov, 1982) "екологічна система - це будьяке угруповання живих істот і середовище його існування, поєднані в одне функціональне ціле завдяки взаємозалежності і причинно-наслідковим зв'язкам, що існують між окремими екологічними компонентами". Це також "інформаційно саморозвиткова, термодинамічно відкрита сукупність біотичних компонентів та абіотичних джерел речовини й енергії, єдність і функціональний зв'язок котрих у межах характерної для певної ділянки біосфери часу і простору забезпечують перевищення на цій ділянці внутрішніх закономірних переміщень речовини, енергії та інформації над зовнішнім обміном (зокрема між сусідніми аналогічними сукупностями) і на основі цього невизначено тривалу саморегуляцію та розвиток цілого під керівним впливом біотичних і біогенних складових".

Поняття "екосистема" - універсальне і загальнобіологічне. Так само, як терміном "організм" означаємо будь-яку одиницю організмового рівня організації - від одноклітинного прокаріота чи еукаріота до великого дерева, високоорганізованої тварини чи людини, так і термін "екосистема" характеризує структурно-функціональну суть усіх одиниць екосистемного ряду- від консорції, через біогеоценоз, ландшафтні екосистеми (біогеосистеми, за Бялловичем), материкові чи океанічні екосистеми аж до біосфери включно (Holubets, 1978).

На підставі багаторічних досліджень карпатських екосистем М. А. Голубець (Holubets, 1997, 1978) розвинув теорію Ю. Одума про екосистемний рівень організації живого. Після додаткового аналізу особливостей самоорганізації, самозбереження і саморегуляції біотичних систем було розкрито механізми саморегуляції екосистем, передовсім, кібернетичну суть їх пам'яті, регулятора, прямих і зворотних зв'язків (Holubets, 1978), а 
згодом опубліковано додаткові матеріали про структуру та еволюцію біосфери (Holubets, 1997). Це дає змогу підійти до обгрунтування складного ландшафтного комплексу (СЛК), як системи. При цьому, завданням епітету "ландшафтний" $\epsilon, 3$ одного боку, зосередити увагу на загальній територіальній комплексності та одиниці, 3 іншого - підкреслити, що до цієї категорії екосистем можна зарахувати природно-територіальні комплекси, які за розмірами відповідають географічному ландшафтові. За П. Г. Шищенком (Shyshchenko, 1990), "географічний ландшафт - це природний чи антропогенний (змінений під впливом діяльності людини) територіальний або акваторіальний комплекс, що являє собою генетично однорідну ділянку (сегмент) ландшафтної сфери з єдиним геологічним фундаментом, однотипним рельєфом, поєднанням грунтів і біогеоценозів і характерною для неї морфологічною структурою. Останню визначають за особливостями взаємодії та взаємозв'язків між речовинними компонентами ландшафту і чинниками його утворення, просторового поєднання його морфологічних одиниць (ландшафтних місцевостей, урочищ, фацій), їх динамікою та розвитком у часі" [згідно з В. М. Сукачовим (Sukachov, 1964), біогеоценоз дорівнює фізико-географічній фації, потрактованій як енергетична система; за В. Б. Сочавою (Sochava, 1978), фація - це об'єднання подібних біогеоценозів].

Під природно-територіальним комплексом у географії розуміють відносно однорідну частину географічної оболонки, що характеризується спільними рисами морфології, структури, функціонування та інтенсивності сучасних природних процесів. Найменшим природнотериторіальним комплексом вважають фацію, найбільшими - географічні ландшафти, їх види, типи і класи (Marynych \& Shyshchenko, 2003). Зважаючи на це маємо підстави стверджувати, що за просторовими межами до категорії "складний ландшафтний комплекс" належить будь-який природно-територіальний комплекс (рангу фізико-географічних фацій, урочищ, місцевостей, ландшафтів), потрактований з екосистемологічних позицій, тобто як функціональна, самоорганізована, саморегульована, енергетична система, носієм організованості якої є жива речовина, за В. І. Вернадським.

СЛК, з огляду на сучасне наукове трактування, має системний характер. Системність - це загальна властивість об'єктивно існуючої єдності СЛК, їх структурованості та взаємозв'язку. Структурованість СЛК полягає в їх дискретності та впорядкованості. Матеріальний світ складається 3 величезної кількості різноманітних дискретних частин. Ці частини утворюють певні структури, що розміщуються на різних рівнях. Дискретні утворення СЛК, будучи цілісними, незмінними, вступають у взаємодію, не втрачаючи своєї індивідуальності. Складний ландшафтний комплекс $є$ цілісним і закономірним поєднанням природних компонентів - ландшафтних комплексів різного рангу, що взаємодіють і утворюють єдину (неподільну) систему.

Взаємодія між системою та зовнішнім середовищем здійснюється за допомогою входів та виходів. Вхід системи - це дія на неї зовнішнього середовища. Вихід системи - результат функціонування системи для досягнення певної мети або іії реакція на вплив зовнішнього середовища. Отже, у загальному вигляді систему (3 контуром зворотного зв'язку) можна зобразити графічно у такий спосіб (рис. 2).

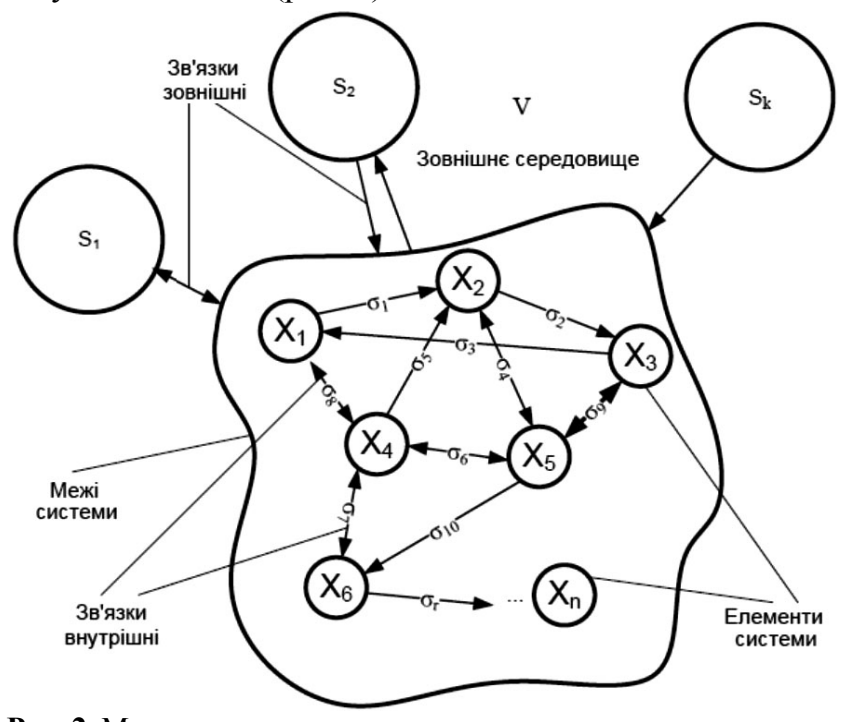

Рис. 2. Модель системи

Ієрархічність будови біосфери зумовлює й ієрархічність систем регуляції рівноваги (гомеостазу) іiі ландшафтних комплексів $\rightarrow$ компартментів $\rightarrow$ підсистем $\rightarrow$ ярусів. Гомеостатичні системи мають генетичну природу й еволюціонують разом зі структурно-функціональною організацією екосистем. Життя не існує поза екосистемами, тому вивчення природних об'єктів будьякого таксономічного рівня ефективне тільки в разі застосування системного підходу.

Саморегуляція, стійкість і надійність складних ландшафтних комплексів. Як наголошено в кібернетичних працях зворотний зв'язок відображає передавання інформації від керованої системи до регулятора, на противагу прямому зв'язку, який забезпечує передавання інформації від регулятора до керованої системи (див. рис. 1). Каналом зворотного зв'язку передається інформація з виходу керованої системи до регулятора про іiі структурно-функціональний стан і про наслідки управлінського впливу інформації, переданої до керованої системи каналом прямого зв'язку. Завдяки діяльності останнього, керована система отримує інформацію на постійне посилення роботи функціональних структур, що призводить до нестійкості роботи системи загалом.

Основну регуляторну функцію, яка забезпечує стійкість і надійність екосистеми, тобто її гомеостазис і гомеорезис, виконує зворотний зв'язок (канал 3 на рис. 1). Якщо, наприклад, за допомогою прямого (генетичного) зв'язку подається інформація на беззастережний ріст, то зворотний зв'язок допомагає відрегульовувати темпи цього росту залежно від умов зовнішнього середовища, в яких існує керована система, від величини речовинноенергетичних ресурсів, збурювального впливу шкідників, конкурентів, консументів, несприятливих фізичних чинників тощо.

Найскладнішим для розв'язання в екосистемологічній кібернетиці виявилося питання про суть і місцезнаходження пам'яті та регулятора екосистеми. Допускаючи методологічно помилкове тлумачення зворотного зв'язку і незважаючи на твердження I. I. Шмальгаузена (Shmalhauzen, 1968), що "всі регуляторні процеси здійснюються завжди за рахунок сил, котрі діють всередині даної системи", різні автори шукали пам'ять у різноманітних структурах екосистеми і поза нею. Наприк- 
лад, А. Н. Тюрюканов (Tiuriukanov, 1970), Г. В. Добровольський та ін. (Dobrovolskyi, et al.,1988) припускали, що вона знаходиться в грунті, а надійність роботи екосистем забезпечують грунтові організми, які здійснюють деструкцію та реутилізацію метаболітів вищих рослин. Ототожнюючи генетичну пам'ять грунту, яка відображає його історію формування й динаміку, та кібернетичну пам'ять екосистеми, С. С. Шварц (Shvarts, 1975) схилявся до думки, що біогеоценоз і популяція підтримують цілісність у мінливих умовах середовища за допомогою біохімічних механізмів гомеостатичних реакцій. М. П. Наумов (Naumov, 1972) стверджував, що єдиною біокібернетичною системою на Землі $\epsilon$ все живе населення. Надорганізмовим живим системам він приписував не тільки такі кібернетичні атрибути, як самоорганізація і доцільна саморегуляція, але й здатність до самовідтворення.

Одум Ю. (Odum, 1986) переконливо доводив, що екосистеми безперечно мають кібернетичну природу й характеризуються кібернетичною поведінкою. Проте він відзначав, що "кібернетичну природу екосистеми важче виявити, зокрема тому, що компоненти на екосистемному рівні пов'язані в інформаційні сітки різни- ми фізичними і хімічними агентами - "посередниками", подібно до того, як нервова чи гормональна система пов'язує в одне ціле частини організму, однак у випадку екосистеми ці зв'язки значно менше помітні (Odum, 1986 , р. 62). Не вдалося збагнути суті саморегуляції екосистем й Л. І. Номоконову (Nomokonov, 1989), услід за Г.Ф. Хільмі (Khylymy, 1975), детальний аналіз 3 цього питання він закінчив висновком про те, що "в основі саморегуляції і самоорганізації біогеоценозу і біосфери ... знаходяться внутрішні процеси, внутрішньосистемні зв'язки і відносини (трофічні, інформаційні та інші), особливо зворотні зв'язки як дія у відповідь одного $з$ внутрішніх компонентів на сильний вплив на нього з боку іншого компонента".

Результати та обговорення. За своєю структурою СЛК, мають чітку ієрархію, що відображається в иї надійності. Розглядаючи СЛК що складається 3 n-рівнів (рис. 3), видно, що система 3 таким типом організації структури помітно надійніша, ніж інші типи структур (наприклад, автономний). Саме ієрархічність просторово-часових характеристик живої матерії дає змогу змоделювати у просторі і часі весь спектр процесів, що забезпечують адаптацію біологічних систем.

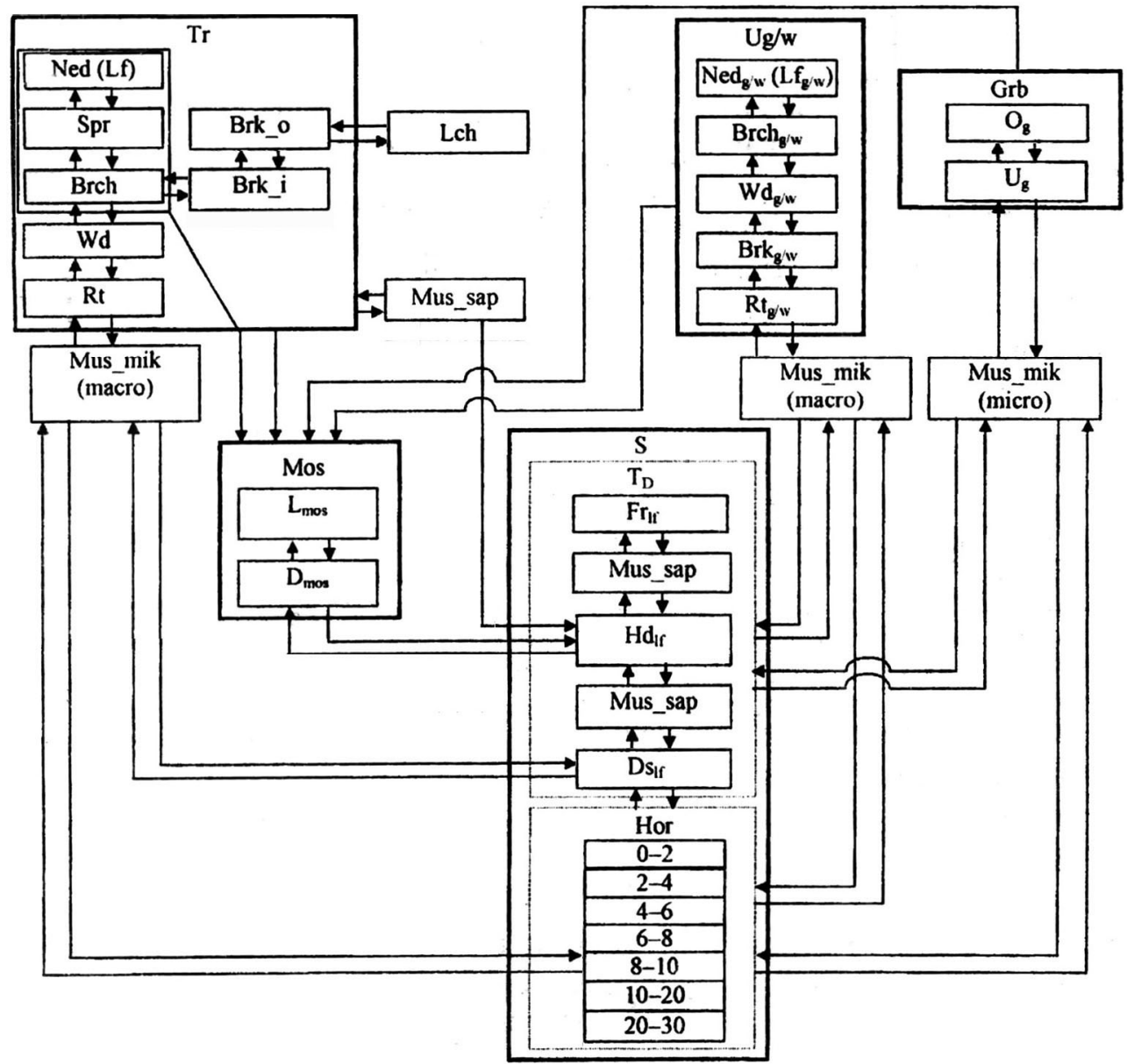

Рис. 3. Концептуальна схема формалізованої моделі лісового компартменту СЛК та зв'язків, що в ньому виникають

На рис. 3 зображено компартмент СЛК, що складається $з$ таких підсистем: деревостан, підріст, підлісок, трав'яно-чагарниковий ярус, моховий ярус, грунт. Кожна підсистема, водночас, складається з ярусів:

• для підсистеми "деревостан" ієрархічно послідовними ярусами $є$ : шпильки (листя)↔пагони поточного рокуњгілкињкора внутрішняњкора зовнішняњдеревина без корињкоріння;
• для підсистеми "підріст" та "підлісок" ієрархічно послідовними ярусами $€$ : шпильки (листя)↔тонкі гілкињстовбурна деревинањкорањкоріння;

• для підсистеми "трав'яно-чагарниковий ярус" ієрархічно послідовними ярусами є: надземна фітомасањпідземна фітомаса;

- для підсистеми "моховий ярус" ієрархічно послідовними ярусами є: жива частинањмертва частина;

- для підсистеми "грунт" ієрархічно послідовними ярусами є: лісова підстилка, що поділяється на: свіжий опадњгриби- 
сапротрофи↔напіврозкладена лісова підстилка $\leftrightarrow$ гриби сапротрофи↔розкладений опад; мінеральні шари: основні горизонтињдодаткові горизонти↔додаткові, відносно відокремлені морфологічні елементи грунту.

- Сама ієрархія, зазвичай розглянута як емпіричний факт відображення відповідної реальності, походить з фундаментального уявлення про потребу реалізації тріади процесів відстеження цільових критеріїв оптимізації:

- екстремального (енергетичного характеру), типу рівностей $\mathrm{i}$ типу нерівностей (обидва - структурного характеру);

- імманентних для кожної трійки суміжних ярусів;

- оптимізації ярусів у складі деякого специфічного контуру управління. Цим самим узагальнюється поняття контуру управління, центрального в однойменній теорії: виникають поняття "супра-контуру" та "ієрархічної оптимізації" (або "супра-оптимізації");

- адаптивної та еволюційної поведінки "супра-системи", що складається з ієрархії "супра-контурів".

Екосистема тим надійніша і стабільніша, чим більше видове різноманіття вона має. Це забезпечує широкі можливості для екологічного дублювання. $€$ очевидним, що рівень здатності екосистеми до повного самовідновлення і саморегулювання протягом сукцесійного або еволюційного часу iï існування, буде показником iï екологічної надійності.

Супра-оптимізація забезпечення механізмів самовідновлення та самозбереження. Оскільки теорію управління (одним 3 розділів якої $\epsilon$ теорія оптимізації) прийнято трактувати як синонім, чи як значну частину кібернетики, то інтерпретацію самовідновлення та самовдосконалення СЛК можна назвати кібернетичною. Відповідно, іiі можна назвати інформаційною, оскільки пропонована концепція, стверджуючи подібність кібернетичних механізмів різних супра-контурів незалежно від реалізації їх матеріального субстрату, акцентує увагу саме на інформаційних взаємодіях у супра-системі.

Вихідні специфічні змінні компартментів формують, з одного боку, деяку сумарну специфічну змінну об'єкта (супра-контуру), а з іншого - є входами для блоку обчислення його цільової функції, вихід якого є визначальним для організації адаптивної поведінки кожного $з$ компартментів. Усі разом, функціонуючи паралельно, вони і реалізують тенденцію безперервного прагнення об'єкта до екстремуму його цільової функції. Сукупність декількох таких ієрархічно пов'язаних супраконтурів $\epsilon$ супра-системою з притаманним їй ієрархічно рандомізованим механізмом адаптивної пошукової оптимізації. У технічній кібернетиці аналогом є ієрархіч- на перевага контурів параметричної та структурної адаптації власне "над" самим процесом оптимізації. Отже, схема ієрархічної оптимізації притаманна для організації насамперед природних систем (за цільовими критеріями енергоструктурного характеру).

Супра-контур компартменту містить такі яруси:

- два яруси систем "основного рівня інтеграції" (OPI): "верхній", що задає критерії оптимізації для всього супра-контуру, i "нижній", що реалізує пошукову активність у супраконтурі;

- два яруси систем "проміжного рівня інтеграції" (ПРІ) також реалізують пошукову активність, але інтегрально: вони $€$ об'єднанням "нижніх" ОРІ-систем, причому ярус "верхній" 3 них представляє собою порівняно неоднорідну структуру, а ярус "нижній" - порівняно однорідну;

і такі зв'язки:

- три виключно внутрішні (для супра-контуру) змінні типу "багато до одного", що задаються підсистемами компартменту обо ПРІ-ярусів і "нижнім" ОРІ-ярусом і діють на розміщені вище підсистеми компартменту ПРІ-ярусів i "верхнього" ОРІ-ярусу відповідно, відображають пошукову активність пристосувальної поведінки компартменту в рамках супра-контуру; кібернетичною мовою можна сказати, що ці змінні характеризують специфічні функціональні активності відповідних ярусів компартментів і $є$ незалежними змінними у відповідних субконтурах оптимізації підсистем компартменту;

- три виключно внутрішні (для супра-контуру) змінні типу "один до багатьох", що задаються підсистемами "верхнього" ОРІ-ярусу і діють на нижні підсистеми ПРІ-ярусів і "нижнього" ОРІ-ярусу відповідно; відображають цільові критерії пристосувальної поведінки компартменту в рамках супра-контуру; кібернетичною мовою можна сказати, що ці змінні керують селекцією варіантів пошукової активності пристосувальної поведінки та еволюції ярусів відповідних підсистем у компартменті;

- три змінні типу "один до багатьох", що генеруються всередині супра-контуру, але впливають не тільки на його підсистеми, але і на компартменти всіх супра-контурів, вкладених у розглянутий; ці змінні відображають пам'ять про траєкторії, iї обмеження (на пошукові змінні типу гіперкуба ï допустимих значень) i результати (значеннях цільових критеріїв) процесу пристосувальної поведінки ярусів кожного компартменту з розглянутого супра-контуру, а також пам'ять про параметри власне механізму оптимізації (лімітування і закону зміни величини пошукового кроку, глибини пам'яті пошукового алгоритму тощо); кібернетичною мовою можна сказати, що ці змінні реалізують процеси адаптації власне процесів оптимізації: параметричної, структурної 1-го рівня, структурної 2-го рівня і т. ін.

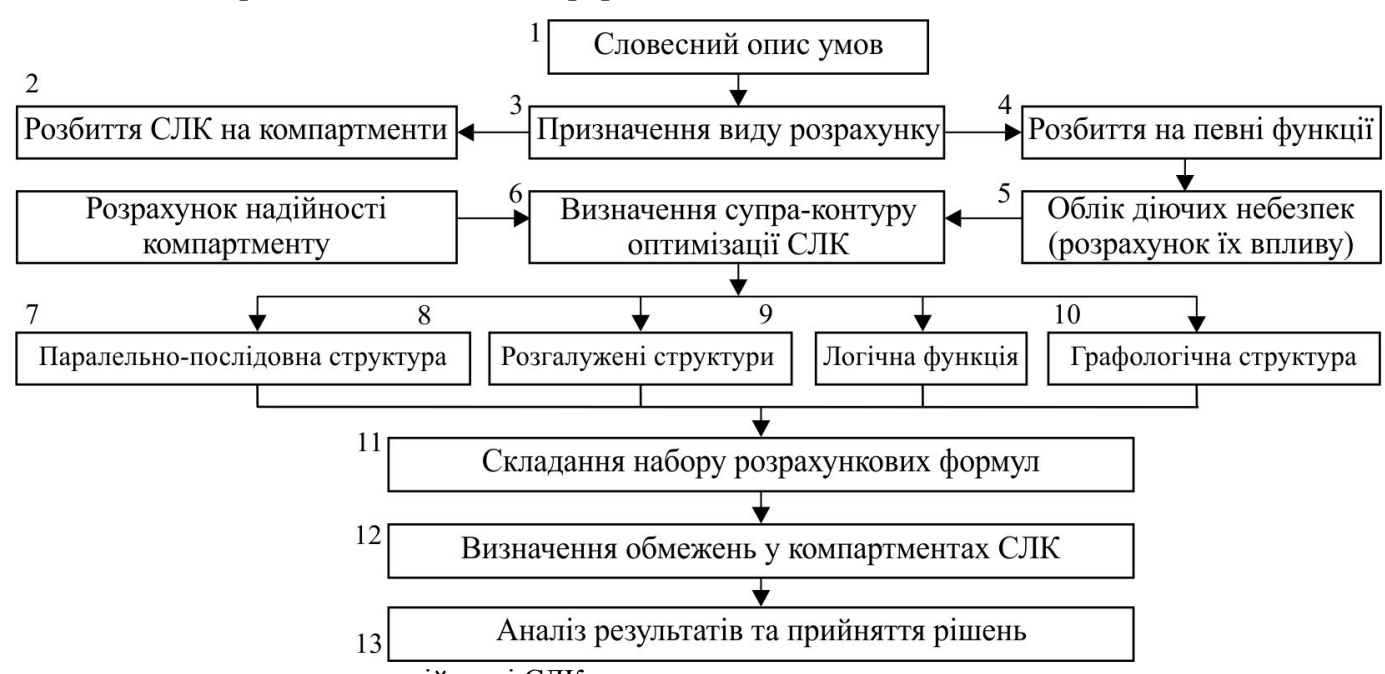

Рис. 4. Концептуальна схема визначення надійності СЛК 
Висновки та рекомендації. Визначивши процес "супра-оптимізації" як процес безперервної еволюції супра-систем, варто виділити фундаментальні особливості такого процесу, зокрема (рис. 4):

а) наявність цільових критеріїв супра-оптимізації; таких як рівності, нерівності чи екстремальні значення функцій;

б) наявність чинників випадковості і регулярності в алгоритмі вибору напрямку і розміру пошукового кроку;

в) уявлення про процеси "розвитку", "поведінки", "еволюції", "адаптації", "модифікації" тощо компартментів в СЛК як супра-системі, які мають єдину природу (сутність);

г) важливість урахування конкретних значень сталих часу перехідних процесів, як окремих пошукових параметрів в оптимізаційному супра-контурі, так і реакції зовнішніх відносно розглянутого супра-контуру складових супра-системи.

Необхідно також чітко сформулювати завдання функціональної організації СЛК, де потрібно вказати: призначення СЛК, іiі склад та основні відомості про функціонування; показники екологічної надійності та ознаки відмов, цільове призначення розрахунків; умови, у яких функціонує СЛК; вимоги до точності й достовірності розрахунків, до повноти обліку діючих антропогенних чинників.

Як вже було вказано, тут простежуються запозичення зі сфери технічної кібернетики - методу випадкового пошуку вирішення завдань оптимізації, який відрізняється від методу "проб і помилок" саме наявністю тенденції пошукового процесу. Окрім випадкової, він містить обов'язкову регулярну компоненту, тобто можливість запам'ятовування критеріїв і результатів попередніх ітерацій. Наприклад застосування цільового критерію енергетичного характеру, що задається в супраконтурі "БГЦ $\rightarrow$ складні організми".

Отже, запропоновано деяку концептуальну схему, що може бути використана як базова модель під час постановки і вирішення найрізноманітніших проблем, що супроводжують надійність біологічної системи, зокрема - модель механізму реалізації процесів адаптації та еволюції СЛК.

\section{Перелік використаних джерел}

Antomonov, Yu. H. (1973). Zvorotnyi zviazok. Entsyklopediia kibernetyky. (Vol. 1). Kyiv: Holov. red. URE, pp. 366-369. [In Ukrainian].
Dazho, R. (1975). Osnovy ekolohyy. Moscow: Prohress, 415 p. [In Russian].

Diuvyno, P., \& Tanh, M. (1968). Byosfera y mesto $v$ nei cheloveka. Moscow: Prohress, 256 p. [In Russian].

Dobrovolskyi, H. V., Hryshyna, L. A., Rozanov, B. H., \& Tarhulian, O. V. (1988). Vlyianye cheloveka na pochvu kak komponent byosfery. Problemy ekolohychesky ustoichyvoho razvytyia byosfery. Moscow: Mosk. otd. Hydrometyoyzdata, pp. 68-78. [In Russian].

Fedorov, V. D., \& Hylmanov, T. H. (1980). Ekolohyia. Moscow: Moscow University Pulishing House, 464 p. [In Russian].

Hlushkov, V. M. (1973). Kibernetyka. Entsyklopediia kibernetyky. (Vol. 1). Kyiv: Holov. red. URE, pp. 473-479. [In Ukrainian].

Holubets, M. A. (1978). Zahalna skhema mekhanizmiv samorehuliatsii v zhyvykh systemakh biosfery. Visnyk AN URSR, 1, 76-85. [In Ukrainian].

Holubets, M. A. (1997). Vid biosfery do sotsiosfery. Lviv: Polli, 254 p. [In Ukrainian].

Khylymy, H. F. (1975). Sovremennoe sostoianye nauchnykh kontseptsyi byosfery. Metodolohycheskye yssledovanyia byosfery. Moscow: Science, pp. 91-100. [In Russian].

Marynych, O. M., \& Shyshchenko, P. H. (2003). Fizychna heohrafiia Ukrainy. Kyiv: Znannia, 480 p. [In Ukrainian].

Naumov, N. P. (1972). Struktura y samorehuliatsyia byolohycheskykh makrosystem. Byolohycheskaia kybernetyka. Moscow: Higher school, pp. 301-361. [In Russian].

Nomokonov, L. Y. (1989). Obshchaia byoheotsenolohyia. Rostov-naDonu: Rostov University Publishing House, p. 288. [In Russian].

Odum, Yu. (1986). Ekolohyia. Moscow: Myr, p. 328 (Vol. 1), p. 376 (Vol. 2). [In Russian].

Poletaev, Y. A. (1958). Syhnal. O nekotorykh poniatyiakh kybernetyky. Moscow: Radyo, 404 p. [In Russian].

Reimers, N. F., \& Yablokov, A. V. (1982). Slovar termynov y poniatyi, sviazannykh s okhranoi zhyvoi pryrody. Moscow: Science, 144 p. [In Russian].

Shmalhauzen, Y. Y. (1968). Kybernetycheskye voprosy byolohyy. Novosybyrsk: Science, 224 p. [In Russian].

Shvarts, S. S. (1975). Ekolohycheskye osnovy okhrany byosfery. Metodolohycheskye aspekty yssledovanyia byosfery. Moscow: Science, pp. 100-112. [In Russian].

Shyshchenko, P. H. (1990). Landshaft heohrafichnyi. Heohrafichna entsyklopediia Ukrainy. (Vol. 2). Kyiv: URE, p. 256. [In Ukrainian].

Sochava, V. B. (1978). Vvedenye $v$ uchenye o heosystemakh. Novosybyrsk: Science, 318 p. [In Russian].

Sukachov, V. N. (1964). Osnovne poniatyia lesnoi byoheotsenolohyy. Osnovy lesnoi byotsenolohyy. Moscow: Science, pp. 5-49. [In Russian].

Tansley, A. S. (1935). The use and abuse of vegetational conceps and terms. Ecology, 16(4), 284-307.

Tiuriukanov, A. N. (1970). Nekotorye aspekty uchenyia o byosfere y byoheotsenoze. Nauch. dokl. vyssh.shkoly. Byol. nauky, 4, 46-52. [In Russian]

T. Gh. Bojko', M. V. Ruda1, M. M. Paslavskyi², S. O. Sokolov³, S. V. Petrenko³, S. I. Skakovskiy³

${ }^{1}$ Lviv Polytechnic National University, Lviv, Ukraine

${ }^{2}$ Ukrainian National Forestry University, Lviv, Ukraine

${ }^{3}$ Luhansk Taras Shevchenko National University, Starobilsk, Ukraine

\section{CIBERNETIC CHARACTER OF COMPOSITE LANDSCAPE COMPLEXES AND SUPRA-OPTIMIZATION OF MECHANISMS OF SELF-REPAIR AND SELF-PRESERVATION}

This article describes the cybernetic character and methods of controlling ecological processes in the ecosystem, that determine its desire for self-preservation and self-improvement, and therefore impossible without self-reproduction and self- restoration. The system and organizational connection in nature are described, and the biosphere is defined as a geographical, thermodynamic, chemical, biotic and cybernetic system. On the basis of the analysis of domestic and foreign literary sources, mechanisms of self-organization, self-preservation and self-regulation of biotic systems have been determined, which enabled approaching the substantiation of the compound landscape complex (CLC) as a system. Systemicity is a common property of the objective existence of the unity of the CLC, their structuring and interconnection. The main regulatory function, which ensures the stability and reliability of the ecosystem, namely homeostasis and homeorhesis, performs the feedback that is based on internal processes, internal system communications and relations (trophic, information, etc.), especially as feedback action in response to one of the internal components for a strong influence on it by another component. The hierarchy of the structure of the biosphere also determines the hierarchy of the systems of regulation of the balance (homeostasis) of its landscape complexes, compartments, subsystems, and layers. These hierarchical spatial and 
temporal characteristics of living matter allow simulating all processes in space and time that ensures the adaptation of biological systems. Output specific components of the compartments are formed as some summary specific object variable (supra-contour), and also are inputs for the block of calculation of its target function, the output of which is decisive for the organization of adaptive behaviour of each compartment. Therefore, the scheme of hierarchical optimization is inherent to the organization of firstly for natural systems (according to the target criteria of the energy-structural character). Determining the process of "supra-optimization" as a process of continuous evolution of supra-systems, the article highlights the fundamental features of such a process, clearly formulating the task of the functional organization of the CLC, and also determines the bonds and connections of the supra-contour of the compartment. The proposed conceptual scheme can be used as the basic model during the formulation and solution of various problems that accompany the reliability of the biological system, in particular, the model of the mechanism of implementation of the processes of adaptation and evolution of the CLC.

Keywords: composite landscape complex; compartment; biogeocenosis; hierarchical; homeostasis; homeorhesis; supra-contour; systemicity; hierarchical optimization; ecological reliability. 